\title{
Stress and protein intake are associated with short sleep duration among hypertensive patients
}

\author{
RATU AYU DEWI SARTIKA ${ }^{A, c, E-G}$, ISNA AULIA FAJARINI ${ }^{\mathrm{D}-\mathrm{F}}$, CLARISSA TIFFANY LESLIE ${ }^{\mathrm{A}-\mathrm{F}}$ \\ ORCID ID: 0000-0001-5018-7625 \\ ORCID ID: 0000-0002-2133-7783
}

Department of Public Health Nutrition, Faculty of Public Health, Universitas Indonesia, Depok, Indonesia

A - Study Design, B - Data Collection, C - Statistical Analysis, D - Data Interpretation, E - Manuscript Preparation, F - Literature Search, G - Funds Collection

Summary Background. Hypertensive patients usually have shorter sleep duration compared to the healthy population. Short sleep duration in hypertensive patients increases the risk of hypertension co-morbidity incidence and is caused by dietary intake, stress or other lifestyle factors.

Objectives. This study aimed to determine the relationship between stress and other factors related with sleep duration in hypertensive patients.

Materials and methods. This study used a cross-sectional design with a sample size of 98 hypertensive patients who regularly received treatment for at least six months prior to data collection. Data was collected at Tegal Gundil Primary Healthcare, West Java, Indonesia, in 2017. Sleep duration was determined through the self-reported method, stress was assessed using the Perceived Stress Scale (PSS) questionnaire, dietary intake using the Semi-Quantitative Food Frequency Questionnaire (SFFQ), physical activity using the Global Physical Activity Questionnaire (GPAQ) and the presence of a roommate using the Pittsburgh Sleep Quality Index (PSQI).

Results. The results showed that the average of hypertensive patients' sleep duration was 6.39 hours, with $54 \%$ of respondents sleeping less than the recommended duration ( 7 hours). A positive correlation was found between stress and sleep duration ( $p=0.020$; $r=0.235)$ and protein intake and sleep duration $(p=0.041 ; r=0.266)$. The presence of a roommate also had a significant relation with sleep duration $(p=0.023 ; \mathrm{OR}=4.45(1.32-15.01))$.

Conclusions. It was found that stress, protein intake and the presence of a roommate were associated with short sleep duration among hypertensive patients.

Key words: sleep, life style, proteins, hypertensive patient.

Sartika RAD, Fajarini IA, Leslie CT. Stress and protein intake are associated with short sleep duration among hypertensive patients. Fam Med Prim Care Rev 2021; 23(1): 65-68, doi: https://doi.org/10.5114/fmpcr.2021.103158.

\section{Background}

Hypertension contributes to $13 \%$ of all deaths globally, with an estimated $60 \%$ of total cases increasing by 2025 [1]. Hypertension is known as an incurable disease, yet blood pressure can be managed through engaging in a healthy lifestyle, such as a healthy diet, adequate physical activity and sufficient sleep duration. However, a cross-sectional study showed that hypertensive patients only had an average of 6.3 hours of sleep per night [2], shorter than that of non-hypertensive patients (6.9 hours) [3]. Insufficient sleep duration could trigger an increase in both systole and diastole blood pressures $[4,5]$. One of the reasons is that shorter sleep duration increases the waking state, which subsequently triggers the sympathetic nervous system to work longer, and thus nighttime blood pressure levels increase [6]. Furthermore, the restorative process in the human body happens during sleep. Consequently, short sleep duration can increase the risk of developing both biological and behavioral chronic diseases.

Shorter sleep duration is commonly caused by lifestyle factors, including stress level and dietary intake [6-8]. A high level of stress is a major predictor of short sleep duration. It was found that acute stress decreases slow-wave sleep and rapid eye movement (REM) [7]. Dietary intake, focusing on specific dietary components, has been shown to have an effect on sleep duration, quality and behaviors [6]. In fact, high carbohydrate, high fat, low protein and low fiber intake are all associated with short sleep duration $[6,8]$.
West Java was the fourth province with the most cases of hypertension in Indonesia. There was a $29.4 \%$ prevalence of hypertension, higher than the national prevalence of $25.8 \%$ [9]. In Bogor specifically, there is a $29.3 \%$ prevalence of hypertension, similar to West Java [10]. Tegal Gundil Health Center is one of the main health centers in Bogor. Hypertension was the most common chronic disease managed there, with 3,409 cases in 2017. As short sleep duration was commonly found in hypertensive patients, it was interesting to see the relationship between sleep and other factors, particularly in Bogor, because it has not been widely studied yet. Therefore, this study aimed to find the relation between stress, dietary intake and other selected factors with sleep duration in patients with hypertension.

\section{Materials and methods}

A cross-sectional design was applied to this quantitative study, which was conducted from July to September 2017. The study included 98 hypertensive patients who satisfied the inclusion criteria as follows: diagnosed with hypertension by health personnel, 25-64 years of age and received regular treatments from Tegal Gundil Health Center, which is located in the northern district of Bogor city, Indonesia, for at least six months prior to data collection. The data was collected through performing anthropometric measurements and interviewing subjects using a set of questionnaires at Tegal Gundil Health Center by trained undergraduate students of nutritional studies.

The studied variables were sleep duration, macro-nutrient and fiber intake, coffee consumption, nutritional status, physi- 
cal activity, stress level, smoking habit and existence of a roommate. Sleep duration was defined as the length of usual sleep time obtained by calculating the difference between sleep and wake time. Intake of macro-nutrient, fiber and coffee were obtained through an interview using the Semi-quantitative Food Frequency Questionnaire (SFFQ), which was then compared to the Indonesian RDA and categorized as "inadequate", "adequate" or "excessive". Protein, fat, carbohydrate and fiber intake was measured in grams per day, energy in calories per day and coffee consumption in cups per day. Anthropometric measurement was used to obtain Body Mass Index (BMI), and height and weight was measured using microtoise and Tanita Weight Scale BC541, respectively. BMI was categorized into "Obese $(\geq 27 \mathrm{~kg} /$ $\left./ \mathrm{m}^{2}\right)$ " and "Not obese $\left(<27 \mathrm{~kg} / \mathrm{m}^{2}\right)$ ", referring to guidelines from the Indonesia Health Ministry of BMI Categorizations for Indonesian Adult. Physical activity was measured using the Global Physical Activity Questionnaire (GPAQ). Stress level was measured using the Perceived Stress Scale (PSS) by considering hard life conditions, such as uncontrolled or unpredictable situations. The roommate variable was distinguished by whether they had a roommate/bedmate or not using a question listed in the Pittsburgh Sleep Quality Index (PSQI). Data concerning smoking was collected through an interview and was subsequently categorized as "currently smoking" or "currently not smoking".

Univariate and bivariate data analysis was performed. The hypothesis of whether there is a correlation between dietary intake and stress with sleep duration in hypertensive patients was checked using the Pearson's correlation and chi-square test; $p<0.05$ was considered to be significant for all tests.

\section{Ethical considerations}

Ethical approval number No. 2/3/UN2.F10/PPM.00.02/2017 was obtained from the Ethics Commission for Research and Public Health Services, Faculty of Public Health, Universitas Indonesia. The participants were also informed about the study and provided both verbal and written consent before the data collection process began.

\section{Results}

Among 98 hypertensive patients (12 males, 96 females) aged 25 years and above who participated in this study, as much as $12.2 \%$ and $87.8 \%$ were categorized to have hypertension grade 1 and 2, respectively. Of all subjects, $45.4 \%$ were diagnosed with hypertension for more than 24 months. The subjects' average sleep duration was 6.39 hours, with $54 \%$ of subjects having a sleep duration shorter than the recommendation ( 7 hours). The participants' average BMI was $27.17 \pm 4.82$ $\mathrm{kg} / \mathrm{m}^{2}$; as much as $51 \%$ and $30 \%$ of the subjects were obese and overweight, respectively. Table 1 presents the distribution of variables in numerical data.

\begin{tabular}{|l|l|l|l|l|}
\hline \multicolumn{5}{|l|}{ Table 1. Distribution of studied variables } \\
\hline Variables & Mean \pm SD & Median & Min & Max \\
\hline Age & $51.70 \pm 8.84$ & 52.50 & 26.00 & 65.00 \\
\hline BMI $\left(\mathrm{kg} / \mathrm{m}^{2}\right)$ & $27.17 \pm 4.82$ & 27.27 & 18.50 & 40.00 \\
\hline Stress & $18.32 \pm 6.77$ & 17.00 & 8.00 & 40.00 \\
\hline $\begin{array}{l}\text { Sleep duration } \\
\text { (hours) }\end{array}$ & $6.38 \pm 1.39$ & 6.50 & 2.00 & 9.25 \\
\hline $\begin{array}{l}\text { Energy intake } \\
\text { (kcal) }\end{array}$ & $1514.82 \pm 564.21$ & 1479.45 & 451.40 & 3128.20 \\
\hline $\begin{array}{l}\text { Protein intake } \\
\text { (g) }\end{array}$ & $53.91 \pm 27.50$ & 47.05 & 8.90 & 138.90 \\
\hline Fat intake (g) & $54.48 \pm 27.80$ & 47.80 & 13.00 & 142.70 \\
\hline $\begin{array}{l}\text { Carbohydrate } \\
\text { intake (g) }\end{array}$ & $202.50 \pm 77.09$ & 190.55 & 56.30 & 421.90 \\
\hline Fiber intake (g) & $10.00 \pm 4.12$ & 9.61 & 1.30 & 24.41 \\
\hline \multicolumn{5}{|l|}{} \\
\hline
\end{tabular}

We found that most of our respondents had a low education background $(71 \%)$ and were unemployed $(81 \%)$. After comparing patients' nutritional intake with the Indonesian RDA, this study discovered that a majority of patients had adequate energy $(52 \%)$, inadequate protein $(64.29 \%)$, adequate carbohydrate (54\%) and inadequate fiber (54\%) Intake.

Statistical analysis showed a significant positive correlation between stress with sleep duration ( $p=0.020 ; r=0.235$ ) (Table 2). A similar correlation was also found between protein intake and sleep duration in hypertensive patients $(p=0.041$; $r=0.266)$. We also found a significant difference in sleep duration between subjects who had a roommate and those who slept alone $(p=0.023 ; \mathrm{OR}=4.45(1.32-15.01))$. Subjects with roommates were $4.46(\mathrm{Cl} 95 \%=1.32-15.01)$ times more likely to have insufficient sleep duration than subjects who slept alone.

\begin{tabular}{|c|c|c|}
\hline \multirow[t]{2}{*}{ Variable } & \multicolumn{2}{|c|}{ Sleep duration } \\
\hline & $p$ & $r$ \\
\hline Energy intake & 0.272 & 0.112 \\
\hline Protein intake & $0.041 *$ & 0.266 \\
\hline Fat intake & 0.256 & 0.116 \\
\hline Carbohydrate intake & 0.411 & 0.084 \\
\hline Fiber intake & 0.935 & 0.008 \\
\hline Coffee consumption & 0.523 & 0.067 \\
\hline Stress & $0.020 *$ & 0.235 \\
\hline
\end{tabular}

*Notes: $p<0.05$ (Pearson's correlation test), $r=$ Pearson's coefficient.

\begin{tabular}{|c|c|c|c|c|c|}
\hline \multirow[t]{3}{*}{ Variable } & \multirow[t]{3}{*}{ Category } & \multicolumn{2}{|c|}{ Sleep duration } & \multirow[t]{3}{*}{$p$} & \multirow[t]{3}{*}{ OR $(95 \% \mathrm{Cl})$} \\
\hline & & Deficient & Sufficient & & \\
\hline & & $n(\%)$ & $n(\%)$ & & \\
\hline Sex & $\begin{array}{l}\text { Male } \\
\text { Female }\end{array}$ & $\begin{array}{l}8(66.7) \\
45(52.3)\end{array}$ & $\begin{array}{l}4(33.3) \\
41(47.7)\end{array}$ & 0.532 & $1.822(0.510-6.506)$ \\
\hline Physical activity & $\begin{array}{l}\text { Active ( } \geq 600 \mathrm{METs} / \text { week) } \\
\text { Inactive (< } 600 \mathrm{METs} / \text { week) }\end{array}$ & $\begin{array}{l}37(58.7) \\
16(45.7)\end{array}$ & $\begin{array}{l}26(41.3) \\
19(54.3)\end{array}$ & 0.304 & $1.690(0.735-3.887)$ \\
\hline BMI & $\begin{array}{l}\text { Obese }\left(\geq 27 \mathrm{~kg} / \mathrm{m}^{2}\right) \\
\text { Not obese }\left(<27 \mathrm{~kg} / \mathrm{m}^{2}\right)\end{array}$ & $\begin{array}{l}16(31.4) \\
10(21.3)\end{array}$ & $\begin{array}{l}35(68.6) \\
37(78.7)\end{array}$ & 0.367 & $1.691(0.677-4.224)$ \\
\hline Roommate & $\begin{array}{l}\text { Have roommate } \\
\text { Sleep alone }\end{array}$ & $\begin{array}{l}49(59.8) \\
4(25.0)\end{array}$ & $\begin{array}{l}33(40.2) \\
12(75.0)\end{array}$ & $0.023 *$ & $4.455(1.322-15.007)$ \\
\hline Smoking & $\begin{array}{l}\text { Currently smoking } \\
\text { Currently not smoking }\end{array}$ & $\begin{array}{l}9(31.0) \\
17(24.6)\end{array}$ & $\begin{array}{l}20(69.0) \\
52(75.4)\end{array}$ & 0.686 & $1.376(0.528-3.590)$ \\
\hline
\end{tabular}




\begin{tabular}{|c|c|c|c|c|c|}
\hline \multirow[t]{3}{*}{ Variable } & \multirow[t]{3}{*}{ Category } & \multicolumn{2}{|c|}{ Sleep duration } & \multirow[t]{3}{*}{$p$} & \multirow[t]{3}{*}{ OR $(95 \% \mathrm{Cl})$} \\
\hline & & Deficient & Sufficient & & \\
\hline & & $n(\%)$ & $n(\%)$ & & \\
\hline Protein intake & $\begin{array}{l}\text { Inadequate } \\
\text { Adequate }\end{array}$ & $\begin{array}{l}32(50.8) \\
21(60.0)\end{array}$ & $\begin{array}{l}31(49.2) \\
14(40.0)\end{array}$ & 0.506 & $0.688(0.298-1.590)$ \\
\hline Fat intake & $\begin{array}{l}\text { Excessive } \\
\text { Adequate }\end{array}$ & $\begin{array}{l}9(18.4) \\
17(34.7)\end{array}$ & $\begin{array}{l}40(81.6) \\
32(65.3)\end{array}$ & 0.109 & $0.424(0.167-1.076)$ \\
\hline Carbohydrate intake & $\begin{array}{l}\text { Excessive } \\
\text { Adequate }\end{array}$ & $\begin{array}{l}10(22.2) \\
16(30.2)\end{array}$ & $\begin{array}{l}35(77.8) \\
37(69.8) \\
\end{array}$ & 0.509 & $0.661(0.265-1.650)$ \\
\hline Energy intake & $\begin{array}{l}\text { Excessive } \\
\text { Adequate }\end{array}$ & $\begin{array}{l}9(19.1) \\
17(33.3)\end{array}$ & $\begin{array}{l}38(80.9) \\
34(66.7) \\
\end{array}$ & 0.174 & $0.474(0.187-1.202)$ \\
\hline Fiber intake & $\begin{array}{l}\text { Inadequate } \\
\text { Adequate }\end{array}$ & $\begin{array}{l}27(50.9) \\
26(57.8)\end{array}$ & $\begin{array}{l}26(49.1) \\
19(42.2)\end{array}$ & 0.636 & $0.759(0.341-1.689)$ \\
\hline
\end{tabular}

\section{Discussion}

It is important for hypertensive patients to have adequate sleep duration to support the hypertension treatment and prevent further increase in blood pressure $[3,5,11,12]$. However, in this study, we found that hypertensive patients had shorter sleep duration when compared to the non-hypertensive population. We also found a positive correlation between stress and sleep duration, this is possibly related to the participants' stress management [13]. It is also found that having inadequate protein intake possibly tryptophan - and a roommate can reduce sleep time [14].

In this study, the average sleep duration of hypertensive patients was 6.39 hours. This is quite similar to the average of sleep duration of hypertensive patients in another study (6.3 hours) [2]. However, these results were lower than the average sleep duration (6.8-6.9 hours) of the general population, as obtained from different studies $[3,11]$. In addition, it did not meet the recommendation sleep time of 7-9 hours for adults [12]. These studies revealed that the sleep duration of hypertensive patients was lower than that of the general population. This result is consistent with the theory that hypertension plays a role in reducing sleep [5]. A decrease in blood circulation in the brain, in areas that are normally active, occurs in hypertensive patients. This can produce cognitive and behavioral changes, such as sleep deprivation and disorders [1]. This can be dangerous for hypertensive patients, because sleep deprivation could, in turn, increase blood pressure $[5,15]$.

In this particular study, a positive correlation was found between stress and sleep duration. Different results were found in another study, which indicated that subjects with higher stress were more likely to have a short sleep duration [16]. However, a similar result was also found in another study, which showed that subjects with depressive symptoms slept 25 minutes longer than subjects with no depressive symptoms [17]. This was possibly related to stress management. A person's response to stress consists of three stages: alarm, resistance and fatigue. In the alarm stage, a fight or flight response occurs while increasing the energy expenditure needed to either defend one's self or run away. In the resistance stage, responses were increased further by ensuring that the body will spread the initial stress response activated by the HPA (hypothalamus-pituitary-adrenal) axis. Finally, in the fatigue stage, the body is no longer able to maintain these responses while experiencing energy loss [13]. There is a possibility that the subjects in this study had emotional fatigue, either related to solving or avoiding their problems.

Additionally, our study confirmed that the proportion of stress among hypertensive patients who were not physically active was higher than those who were active. The systematic physical activity performed by patients with treatment-resistant arterial hypertension reduces anxiety, symptoms of depression and pain intensity [18].

Gender was also a contributing factor in stress management. Men were more likely to solve problems, while women were more likely to avoid problems [16]. The subjects in this study were mostly females, with a higher average stress score (18.6) than males (16.17). Thus, there was a possibility that the female subjects preferred to avoid problems through sleeping.

Among hypertensive patients who had 'deficient' sleep duration, the proportion of those with roommates was higher than those who slept alone. This was in contrast to another study, which indicated longer sleep duration in adults with roommates than in adults who slept alone. However, the quality of the relationship was very crucial in this. A bad relationship and communication could decrease sleep duration, affect physical and mental health and influence the household [19]. Furthermore, roommates could also cause noise (such as snoring or from using electronic devices), which was the biggest source of sleep disturbance [20]. Potentially, disturbances from roommates could disrupt the subjects' sleep.

A bidirectional relationship between sleep duration and dietary intake currently exists [21]. A correlation between protein intake and sleep duration was found in this study and is in keeping with several other studies in which subjects who had 'deficient' sleep duration also had lower protein intake $[6,8]$. A positive correlation between protein intake and sleep duration might be caused by foods that are rich with tryptophan, such as egg whites, seafood and soybean by-products [14]. Such products were often consumed by subjects in this study. Tryptophan, an essential amino acid commonly found in protein-rich foods, directly correlates with sleep, given its abilities to increase drowsiness and sleep time. Moreover, tryptophan is a serotonin precursor, which is also associated with sleep duration. Because serotonin is a precursor in melatonin production, one of the most effective ways for serotonin to affect sleep is through changes in melatonin levels [22]. Therefore, a low protein intake was associated with short sleep duration.

It would be necessary to perform a larger-scale study to compare the results. Further studies using more types of studies other than cross-sectional could be carried out to supplement the results in order to show the cause and effect.

\section{Conclusions}

A low protein intake, high stress levels and the presence of a roommate were found as the risk factors of short sleep duration in hypertensive patients. This result indicates the importance of promoting longer sleep duration as a secondary and tertiary measure for patients with hypertension through encouraging patients to increase protein consumption and manage stress in order to prevent the incidence of hypertension comorbidity.

Acknowledgements. This article's publication is supported by the United States Agency for International Development (USAID) through the Sustainable Higher Education Research Alliance (SHERA) Program for Universitas Indonesia's Scientific Modeling, Application, Research and Training for City-centered Innovation and Technology (SMART CITY) Project, Grant \#AID497-A-1600004, Sub Grant \#IIE-00000078-UI-1. 
Source of funding: This work was funded from the authors' own resources.

Conflicts of interest: The authors declare no conflicts of interest.

\section{References}

1. Hanus JS, Amboni G, da Rosa MI, et al. The quality and characteristics of sleep of hypertensive patients. Rev da Esc Enferm 2015; 49(4): 594-599.

2. Bruno RM, Palagini L, Gemignani A, et al. Poor sleep quality and resistant hypertension. Sleep Med 2013; 14(11): 1157-1163.

3. Hwang HR, Lee JG, Lee S, et al. The relationship between hypertension and sleep duration: an analysis of the fifth Korea National Health and Nutrition Examination Survey (KNHANES V-3). Clin Hypertens 2015; 21(1): 8.

4. Akdemir I, Altunbaş G, Ercan S, et al. Impact of acute sleep deprivation on aortic elastic properties in healthy workers. Turk J Med Sci 2013; 43(2): 279-282.

5. Gangwisch JE. A review of evidence for the link between sleep duration and hypertension. Am J Hypertens 2014; 27(10): $1235-1242$.

6. Hwang HR, Lee JG, Lee S, et al. The relationship between hypertension and sleep duration: an analysis of the fifth Korea National Health and Nutrition Examination Survey (KNHANES V-3). Clin Hypertens 2015; 21: 8.

7. Almojali Al, Almalki SA, Alothman AS, et al. The prevalence and association of stress with sleep quality among medical students. J Epidemiol Glob Health 2017; 7(3): 169-174.

8. Grandner MA, Jackson N, Gerstner JR, et al. Dietary nutrients associated with short and long sleep duration. Data from a nationally representative sample. Appetite 2013; 64: 71-80.

9. Indonesia Health Ministry. Basic Health Research Year 2013 (RISKESDAS 2013). Jakarta: Indonesia Health Ministry; 2013.

10. Pradono J, Suparmi S, Sihombing N. Prevalence and determinants of hypertension in aged 15-60 years old in Bogor City, West Java Province Indonesia. Jurnal Ekologi Kesehatan 2013; 12(3): 171-179.

11. Takeuchi H, Taki Y, Nouchi R, et al. Shorter sleep duration and better sleep quality are associated with greater tissue density in the brain. Sci Rep 2018; 8(1): 8533.

12. Knutson KL, Phelan J, Paskow MJ, et al. The National Sleep Foundation's sleep health index. Sleep Health 2017; 3(4): $234-240$.

13. Krajewski KL. The relationship between stress and exercise with fatigue and sleep quality as mediating variables [dissertation]. Dearborn: University of Michigan-Dearborn; 2017.

14. Palego L, Betti L, Rossi A, et al. Tryptophan biochemistry: structural, nutritional, metabolic, and medical aspects in humans. J Amino Acids 2016; 2016: 8952520.

15. Grandner M, Mullington JM, Hashmi SD, et al. Sleep duration and hypertension: analysis of $>700,000$ adults by age and sex. J Clin Sleep Med 2018; 14(6): 1031-1039.

16. Faber J, Schlarb AA. The relation of sleep, distress, and coping strategies - what male and female students can learn from each other? Health 2016; 8(13): 1356-1367.

17. Garfield V, Llewellyn $\mathrm{CH}$, Kumari M. The relationship between physical activity, sleep duration and depressive symptoms in older adults: The English Longitudinal Study of Ageing (ELSA). Prev Med Reports 2016; 4: 512-516.

18. Kruk PJ, Nowicki M. Effects of regular physical activity on pain, anxiety, and depression in patients with treatment-resistant arterial hypertension. Fam Med Prim Care Rev 2016; 18(3): 268-273.

19. Chen JH, Waite LJ, Lauderdale DS. Marriage, relationship quality, and sleep among U.S. older adults. J Health Soc Behav 2015; 56(3): 356-377.

20. Park MJ, Yoo JH, Cho BW, et al. Noise in hospital rooms and sleep disturbance in hospitalized medical patients. Environ Health Toxicol 2014; 29: e2014006.

21. Frank S, Gonzalez K, Lee-Ang L, et al. Diet and sleep physiology: public health and clinical implications. Front Neurol 2017 ; 8: 1-9.

22. Jenkins TA, Nguyen JCD, Polglaze KE, et al. Influence of tryptophan and serotonin on mood and cognition with a possible role of the gut-brain axis. Nutrients 2016; 8(1): 1-15.

Tables: 3

Figures: 0

References: 22

Received: 16.09 .2020

Reviewed: 1.10 .2020

Accepted: 11.02 .2020

Address for correspondence:

Prof. Ratu Ayu Dewi Sartika

Department of Public Health Nutrition

Faculty of Public Health

Universitas Indonesia

Depok

Indonesia

Tel.: +62 217863501

E-mail: ratuayu.fkm.ui@gmail.com, isnaaf7@gmail.com 